\title{
Comparative study of physicochemical and thermal properties of the seed oils of three cucurbit species
}

\author{
Grodji Albarin GBOGOURI ${ }^{1 *}$, Kouakou BROU ${ }^{1}$, Michel LINDER ${ }^{3}$, \\ Elmira Arab TEHRANY ${ }^{3}$, Dago GNAKRI ${ }^{1}$ and Irié Arsène ZORO BI ${ }^{2}$ \\ ${ }^{I}$ Université d'Abobo Adjamé, UFR des Sciences et Technologies des Aliments, Laboratoire de Nutrition et \\ Sécurité Alimentaire, 02 BP 801 Abidjan 02 (Côte d'Ivoire). \\ ${ }^{2}$ Université d'Abobo Adjamé, UFR des Sciences de la Nautre, Laboratoire de Génétique, 02 BP 801 Abidjan 02 \\ (Côte d'Ivoire). \\ ${ }^{3}$ Institut National Polytechnique de Lorraine, Laboratoire d'Ingénierie des Biomolécules, 2 avenue de la forêt \\ de Haye, BP -172, 54505 Vandoeuvre - les Nancy (France). \\ "Corresponding author, E-mail: albaringrodji@yahoo.fr, Tel :0022522500621/0022503384619.
}

\begin{abstract}
Three indigenous cucurbit seeds from Ivory Coast namely Cucumeropsis mannii Naudin, Citrullus lanatus var. Citroides (Thrumb.) Matsum \& Nakai and Cucumis melo var. Agrestis were investigated for the physicochemical properties. Thermal properties of their crude oils extracted by a cold solvent method were also tested. Physicochemical characterization of the seeds showed that they are important sources of proteins, lipids, carbohydrates and mineral elements. $C$. lanatus seeds had the highest lipid content $(46.40 \%)$ followed by $C$. melo seeds (36.50\%) and C. mannii seeds (35.70\%) on dry weigh bases. Most of the index values and chemical characteristics of extracted seed oils are not significantly different, except for the peroxide value and the color parameters of C. mannii. Linoleic acid, whose values ranged from $54.84 \%$ to $70.76 \%$, was the major fatty acid out of all seed oil species. The thermal properties revealed that $C$. melo seed oil had low transition temperatures followed by $C$. lanatus seed oil and $C$. mannii seed oil depending on their fatty acid compositions. These results suggest that these thermal properties could be used in the industrial fractionation and the cucurbit seed oils may be used as edible oils due to their similarity to the commonly used edible oils.
\end{abstract}

(C) 2011 International Formulae Group. All rights reserved.

Keywords: Cucurbit seed oil, physicochemical properties, differential scanning calorimetry, fatty acid.

\section{INTRODUCTION}

Cucurbits species are a prized food for their oleaginous seeds. Their kernels are consumed as thickener soup called pistachio soup in Ivory Coast, egussi soup in Nigeria. In Ivory Coast, certain species of cucurbit are cultivated in small scales for their oily seeds. Citrullus lanatus, Cucumeropsis mannii and Cucumeropsis melo are most abundant compared to Cucurbita pepo and Lagenaria siceraria (Zoro Bi et al., 2006).

Zoro Bi et al. (2006) reported a review of the inter- and intraspecies diversity of cucurbit species consumed in sauce in Ivory Cost: C. melo is locally called lomi n'gatê. Its seeds are toasted, ground and used as sauce thickener. The flesh of their fruits is light green and has bitter taste. C. lanatus locally 
called wlêwlê, is the most common edible cucurbit cultivated in Ivory Coast. Their fruits are round or oval, uniformly light green or mottled light. C. mannii locally called n'viêlê, is a monocious annual climbing vine. Their fruits are uniformly light green or yellowish and blocky.

Some reports available on the composition of seeds and seed kernels of cucurbits indicated that they are rich in macronutrients: lipids, proteins and carbohydrates (Badifou, 1991a, 1991b; De Mello et al., 2000; Badifou, 2001; Loukou et al., 2007). The content of macronutrients varies between $20 \%$ and $50 \%$ depending on the species and the geographical regions. Teotia and Ramakrishna (1984) reported that the seeds of melon grown in India contained from 40 to $47 \%$ of oils and from 23 to $36 \%$ of proteins. Rashwan et al. (1993) showed that lipid and protein contents (on dry weight basis) for seed kernels of sweet melon varieties of C. melo were approximately $37 \%$ and $54 \%$, respectively. In short, many studies on cucurbit varieties reported that they are an important oil source for human diet, a source of energy and carbon building blocks.

In Ivory Coast, the major source of commercial edible oil is palm. That is undoubtedly due to the failure to recognize the characteristics and sources of vegetable oil. However, studies of the properties of other vegetable oils on the laboratory scale could allow them to be used as edible. As seen above, cucurbit seeds were an important source of oil.

The purpose of this investigation is to obtain information about the chemical, the fatty acid composition and thermal characteristics of oils extracted from three species of cucurbit seeds ( $C$. lanatus, $C$. mannii and $C$. melo) in order to determine their suitability as edible oil.

\section{MATERIALS AND METHODS}

Source of seeds and sample preparation

Sun-dried cucurbit seeds of $C$. mannii Naudin, C. lanatus var. Citroides (Thrumb.) Matsum \& Nakai. and C. melo var. Agrestis
(Photographs 1), were obtained from the Laboratory of genetic of University of AboboAdjamé (Ivory Coast). Seeds were crushed in a coffee grinder and stored in hermetic bags at $-20{ }^{\circ} \mathrm{C}$ until analysis.

Morphological characteristics of seeds were examined for weight and size $(\mathrm{n}=100)$ (estimated as length and width).

\section{Proximate composition analyses}

Crude protein was analyzed using the Kjeldahl Method (AOAC, 1997) with nitrogen analyzer (Gerhadt Vapodest, 50, Germany). Dry matter was determined gravimetrically after drying sample overnight at $105^{\circ} \mathrm{C}$. Lipid content was determined using the method of Folch et al. (1957). Ash was quantified after incinerating the sample in the muffle furnace at $550{ }^{\circ} \mathrm{C}$ overnight and minerals (potassium, sodium, calcium, magnesium) were analyzed by atomic absorption spectrophotometry (Perkin Elmer, Model 1100, Paris, France) following the method used by Idouraine et al. (1995). Carbohydrates content was determined through the method used by Samant and Rege (1989).

Energetic density (ED) was calculated with $4 \mathrm{kcal} / \mathrm{g}$ for carbohydrates, $4 \mathrm{kcal} / \mathrm{g}$ for proteins and $9 \mathrm{kcal} / \mathrm{g}$ for lipids according to Atwater and Benedict (1902).

Equation 1: $\mathrm{ED}=[($ Protein content $\times 4)+$ $($ Lipid content $\times 9)+($ Carbohydrate content $\times$ 4)] $\times$ Dry matter content / 100 .

Lipid index was analyzed using standard procedures: peroxide value (Standard 965.33) of the AOCS (1997), acid value and free fatty acids (Norme Européenne, NF EN ISO 660, 1999), iodine value (Norme Européenne, NF EN ISO 3961, 1999) and unsaponifiable matter (Norme Internationale, ISO 18609, 2000).

The CIE L* $a^{*} b^{*}$ coordinates of oils were directly read with a chromameter (Minolta) calibrated with white tile according to the method used by Besbes et al. (2004). In the color coordinate system, the $\mathrm{L}^{*}$ is a measure of lightness and varies from +100 (white) to 0 (black), a* varies from +100 (red) to -100 (green) and $b^{*}$ varies from +100 
(yellow) to -100 (blue).

The chroma value and hue angle value of oils were calculated as $\left(a^{* 2}+b^{* 2}\right)^{1 / 2}$ and [tan-1(b*/a*)], respectively.

Bulk density of seed oils was determined using a $25 \mathrm{~mL}$ measuring cylinder at $22{ }^{\circ} \mathrm{C}$. The sample was filled to a $25 \mathrm{~mL}$ cylinder, the weight to volume ratio was determined, and bulk density value reported as gram per millilitre. Specific gravity was calculated as the density of seed oil divided by density of water at $22{ }^{\circ} \mathrm{C}$.

\section{Gas chromatography analyses}

Fatty acid methyl esters (FAME) were obtained by transmethylation of lipid aliquots (100 mg). According to Ackman (1998), samples were dissolved with $1.5 \mathrm{~mL}$ of hexane and $1.5 \mathrm{~mL}$ of borontrifluoride in methanol $(8 \%, \mathrm{w} / \mathrm{v})$, and heated at $100{ }^{\circ} \mathrm{C}$ under nitrogen for $1 \mathrm{~h}$. After cooling, the fatty acid methyl esters were extracted in hexane under nitrogen.

FAME were analyzed by gas chromatography on Perichrom $^{\mathrm{TM}} 2000$ system (Saulx-les-Chartreux, France), equipped with a flame ionisation detector (FID) and fused silica capillary column $(50 \mathrm{~m} \times 0.25 \mathrm{~mm} \times 0.5$ $\mu \mathrm{m}, \quad$ BPX70 SGE Australia Pty Ltd). Temperatures were set as follows: $2 \mathrm{~min}$ initial period at $120{ }^{\circ} \mathrm{C}$, increasing at 40 ${ }^{\circ} \mathrm{C} / \mathrm{min}$ to the second step at $180{ }^{\circ} \mathrm{C}$ for $8 \mathrm{~min}$, and flowing out at $3{ }^{\circ} \mathrm{C} / \mathrm{min}$ to the final period at $220{ }^{\circ} \mathrm{C}$ for $45 \mathrm{~min}$. Injection and detector ports were maintained at $230{ }^{\circ} \mathrm{C}$ and $260{ }^{\circ} \mathrm{C}$, respectively. Fatty acids were identified by comparing their relative retention time with appropriate vegetable standards and marine PUFA 2 standards from Supelco (Supelco Park, Bellefonte, PA 16823-0048 USA). The results, made in triplicate, were displayed as percent of total identified fatty acids.

\section{Differential Scanning Calorimetry analysis} Thermal characteristics of oils were measured using Differential Scanning Calorimeter (DSC 204 F1 Phoenix ${ }^{\circledR}$, Netzsch Gerätebau GmbH, Germany). Purified nitrogen $(99.9 \%)$ was the purge gas and flowed at $20 \mathrm{~mL} / \mathrm{min}$. The calorimeter was calibrated according to the standard procedures established by the manufacturer user book using indium and water. Approximately, 8-10 mg of sample were weighed into aluminium pans and covers were hermetically sealed into place while an empty hermetically sealed aluminium was used as reference. The sample and the reference pans were then placed inside the calorimeter and subjected to the following temperature program: heating to $50{ }^{\circ} \mathrm{C}$ and holding for 5 min. Cooling to $-50{ }^{\circ} \mathrm{C}$ at the rate of $5{ }^{\circ} \mathrm{C} / \mathrm{min}$ and holding for $5 \mathrm{~min}$. Heating from $-50{ }^{\circ} \mathrm{C}$ to $50{ }^{\circ} \mathrm{C}$ at $5{ }^{\circ} \mathrm{C} / \mathrm{min}$. The transition temperatures, enthalpies of fusion or of crystallization $(\mathrm{J} / \mathrm{g})$ were calculated using the Proteus ${ }^{\circledR}$ Software for thermal analysis ( DSC 204 F1 Phoenix ${ }^{\circledR}$ Netzsch - Gerätebau GmbH, Germany).

\section{Statistical analysis}

Results are expressed as the mean \pm standard deviation of several sample with Kyplot (version 2.0 beta 15, ${ }^{\circledR} 1997-2001$, Koichi Yoshioka) statistical software. The data were statistically analyzed by one way analysis of variance (ANOVA). Means were compared by Turkey's test. Differences were considered statistically significant at $\mathrm{P}<0.05$.

\section{RESULTS}

\section{Physicochemical characteristics of cucurbit seeds}

The physicochemical characteristics of cucurbit seeds are shown in Table 1. The morphological aspect exhibited significant differences $(\mathrm{P}<0.05)$ between seeds for weight and size. C. melo seeds size is small, up to $0.55 \mathrm{~cm}$ (length) and weigh around $12 \mathrm{mg}$. $C$. lanatus seeds are yellowish and weigh around $45 \mathrm{mg}$. The seeds of $C$. mannii are large compared to those of the other two species. Their weight is around $184 \mathrm{mg}$ and their length is around $1.95 \mathrm{~cm}$.

There were significant differences $(\mathrm{P}<0.05)$ among the seeds species in their content of total crude protein, total crude lipid, total carbohydrates and ash (Table 1). The 
protein content was $28.6 \%, 35.6 \%$ and $37.3 \%$ of dry matter for $C$. lanatus, $C$. mannii and $C$. melo, respectively. The carbohydrate content of the three species varied from $22 \%$ to $25 \%$.

The cucurbit species analyzed in this work contain total lipids ranging from $35 \%$ to $46 \%$ of dry matter. $C$. lanatus seeds have the highest fat content (46\%) compared to $C$. mannii seeds (35.7\%) and C. melo seeds $(36.5 \%)$.

There were great variations in the mineral content of the seed samples (Table 2). The potassium content, $806.1 \mathrm{mg} / 100 \mathrm{~g}$ for $C$. mannii and $500 \mathrm{mg} / 100 \mathrm{~g}$ for $C$. lanatus, was much higher than sodium, calcium and magnesium content in the three species. Calcium was the most abundant mineral element in $C$. melo seeds with the content up to $1426 \mathrm{mg} / 100 \mathrm{~g}$, around 14 times the level found for C. mannii seed oil (102 mg/100g) and around 31 times the level found for $C$. lanatus. Sodium content was low in the three sample seeds. It reached $28 \mathrm{mg} / 100 \mathrm{~g}$ for $C$. melo, $11 \mathrm{mg} / 100 \mathrm{~g}$ for $C$. mannii and 43 $\mathrm{mg} / 100 \mathrm{~g}$ for $C$. lanatus.

\section{Physicochemical properties of oils}

Physicochemical properties of seed oils are shown in Table 3 . The peroxide value of $9.78 \mathrm{meq} \mathrm{O}_{2} / \mathrm{kg}$ of oil for $C$. mannii is significantly higher than $1.10 \mathrm{meq} \mathrm{O}_{2} / \mathrm{kg}$ of oil for C. lanatus and than $2.72 \mathrm{meq} \mathrm{O}_{2} / \mathrm{kg}$ of oil for C. melo. There is no significant difference $(\mathrm{P}>0.05)$ in the iodine value of the three species of cucurbit seeds : $115.5 \mathrm{~g}$ of $\mathrm{I}_{2} / 100 \mathrm{~g}$ of oil for C. melo, $111.8 \mathrm{~g}$ of $\mathrm{I}_{2} / 100 \mathrm{~g}$ of oil for C. mannii and $113 \mathrm{~g}$ of $\mathrm{I}_{2} / 100 \mathrm{~g}$ of oil for C. lanatus.

The level of total free fatty acids of $C$. melo and C. mannii (1.13\%) were ca. two times lower than the values of $C$. lanatus $(2.15 \%)$ (Table 3). Oils extracted from cucurbit seeds were fluid at room temperature $25 \pm 2{ }^{\circ} \mathrm{C}$, and had an odor and color depending on the species. The $C$. melo seed oil was pale yellow, $C$. lanatus seed oil was yellow orange and $C$. mannii seed oil was green-yellow. Color data analysis showed a significant difference $(\mathrm{P}<0.05)$ in the color parameters of seed oils. The colour intensity (Chroma value) of $C$. melo and C. mannii seed oils $(0.08 ; 0.09$ respectively) was higher than C. lanatus seed oil (0.06).

The bulk density and the specific gravity of oils were not significantly different $(\mathrm{P}>0.05)$ and ranged from 0.94 to 0.95 and from 0.95 to 0.96 , respectively. The unsaponifiable matters content which is up to $0.5 \%$, was identical for the three oils.

\section{Fatty acids composition}

The main fatty acid compositions of cucurbit seed oils are shown in Table 4. The fatty acid composition of investigated species contained essentially four fatty acids with no significant difference $(\mathrm{P}>0.05)$. Linoleic acid (C18:2n 6) was largely predominant, $70.76 \%$ for C. melo, $63.94 \%$ for C. lanatus and $54.84 \%$ for $C$. mannii. Palmitic acid (C16:0) and stearic acid (C18:0) contents were comparable in each species. Their contents were high in C. mannii and reached $16.33 \%$ for palmitic acid and $13.89 \%$ for stearic acid. The oleic acid content was 9.12\%, 14,54\% and $14.43 \%$ for C. melo, C. mannii and $C$. lanatus, respectively. Linolenic acid (C18:3n 3 ) was present in lower amount (0.42 - 0.46 $\%)$ in the investigated species. The total polyunsaturated fatty acids for C. melo $(71.22 \%)$ were higher than total polyunsaturated fatty acids for $C$. lanatus (64.54\%) and for C. mannii (55.23\%). The amount of unsaturated n- 6 was very high in the three oils, therefore the TUFA/TSFA ratio ranged from 2.30 to $4.10 \%$ of investigated oils.

\section{Thermal properties}

Thermal properties were performed using DSC to assess physical properties of seed oils. Figures 1 and 2 showed the DSC melting and cooling curves for the three cucurbits seed oils. All DSC data are summarized in Tables 5 and 6. The melting curves of oils showed three to four endothermic peaks ranging from $-48.5{ }^{\circ} \mathrm{C}$ to $1.3{ }^{\circ} \mathrm{C}$ for $C$. melo, $-39.5^{\circ} \mathrm{C}$ to $13.8^{\circ} \mathrm{C}$ for $C$. mannii and $-47.7{ }^{\circ} \mathrm{C}$ to $6.0^{\circ} \mathrm{C}$ for $C$. lanatus. The melting curves showed four peaks for $C$. melo (three peaks and two shoulders), four peaks for $C$. lanatus (two peaks and two shoulders), three peaks for $C$. mannii (two peaks and one shoulder) (Figure 1). The $C$. melo seed oil melting curve showed the lowest 
onset and offset temperatures $\left(-48.7{ }^{\circ} \mathrm{C}\right.$ and $1.4{ }^{\circ} \mathrm{C}$, respectively), followed by $C$. lanatus seed oil $\left(-47.7{ }^{\circ} \mathrm{C}\right.$ and $6{ }^{\circ} \mathrm{C}$ respectively). The C. mannii seed oil melting curve showed the highest onset and offset temperatures (-39.5 ${ }^{\circ} \mathrm{C}$ and $13.8^{\circ} \mathrm{C}$, respectively) (Table 6).

The cooling curves (Figure 2) showed two exothermic peaks at $-13.0{ }^{\circ} \mathrm{C}$ and -36.5 ${ }^{\circ} \mathrm{C}$ for $C$. melo, at $-3.5^{\circ} \mathrm{C}$ and $-35.5^{\circ} \mathrm{C}$ for $C$. mannii and at $-10{ }^{\circ} \mathrm{C}$ and $-39.5{ }^{\circ} \mathrm{C}$ for $C$. lanatus. The onset temperature of crystallization (Table 6) was higher for $C$. mannii oil $\left(1.3^{\circ} \mathrm{C}\right)$ than the $C$. lanatus oil ($4.4^{\circ} \mathrm{C}$ ) and the $C$. mannii oil $\left(-7.2^{\circ} \mathrm{C}\right)$.

The melting enthalpy (Table 6) of $C$. lanatus oil was high $(56.0 \mathrm{~J} / \mathrm{g})$, followed by $C$. mannii oil $(47.8 \mathrm{~J} / \mathrm{g})$ and by $C$. melo oil $(39.0$ $\mathrm{J} / \mathrm{g})$. The crystallization enthalpies of oils were between $-24.0{ }^{\circ} \mathrm{C}$ and $-33.0^{\circ} \mathrm{C}$ (Table 6).
A

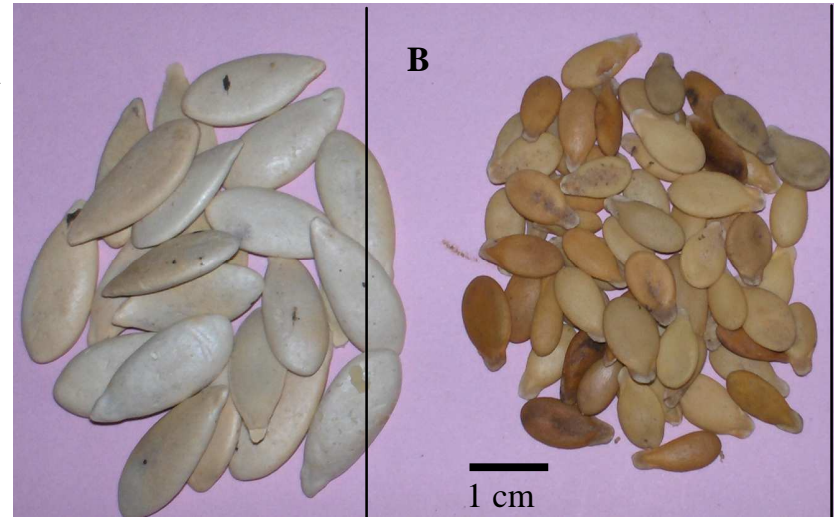

C

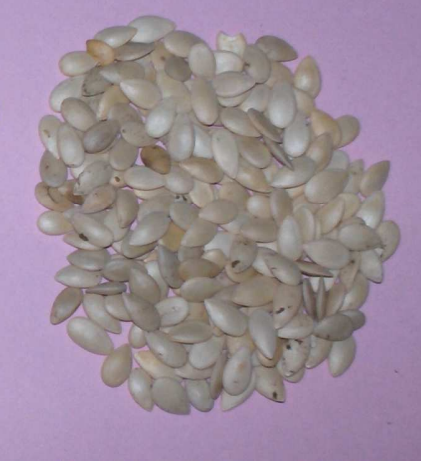

Photographs 1: Seeds of cucurbit species. A: C. mannii Naudin; B: C. lanatus var. Citroides (Thrumb.) Matsum \& Nakai.; C: C. melo var. Agrestis L.

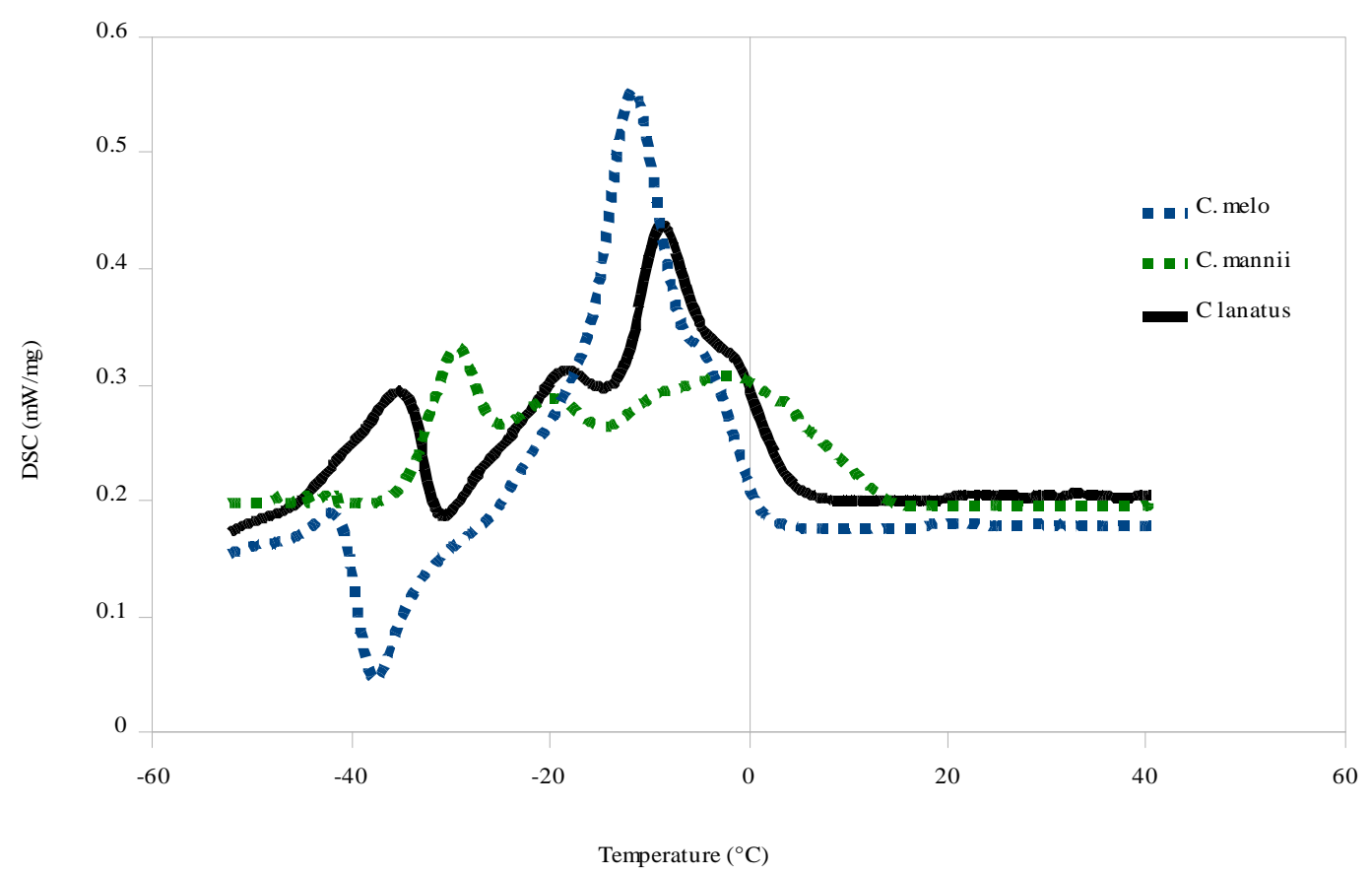

Figure 1: DSC melting curves of cucurbit seed oils at heating rate of $5{ }^{\circ} \mathrm{C} / \mathrm{min}$. 


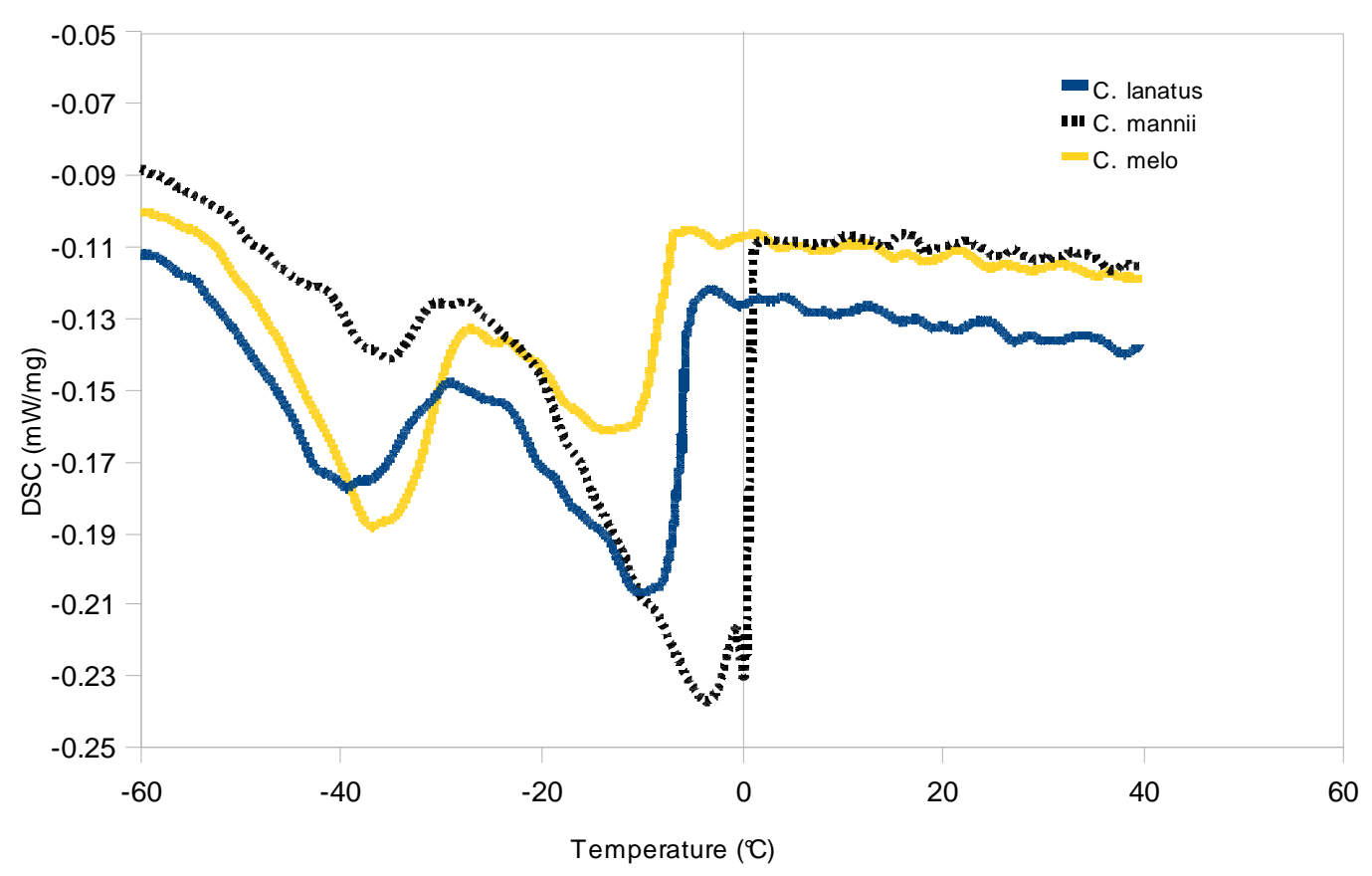

Figure 2: DSC cooling curves of cucurbit seed oils at cooling rate of $5{ }^{\circ} \mathrm{C} / \mathrm{min}$.

Table 1: Physical characteristics and proximate composition of indigenous cucurbit seeds.

\begin{tabular}{|c|c|c|c|c|}
\hline & & C. melo & C. mannii & C. lanatus \\
\hline \multirow[t]{3}{*}{$\begin{array}{l}\text { Morphology } \\
(\mathbf{n}=\mathbf{1 0 0})\end{array}$} & Weight (g) & $0.012 \pm 0.003^{\mathrm{a}}$ & $0.184 \pm 0.006^{\mathrm{c}}$ & $0.045 \pm 0.005^{b}$ \\
\hline & Length $(\mathrm{cm})$ & $0.55 \pm 0.05^{\mathrm{a}}$ & $1.95 \pm 0.06^{\mathrm{c}}$ & $1.22 \pm 0.21^{\mathrm{b}}$ \\
\hline & Width (cm) & $0.34 \pm 0.02^{\mathrm{a}}$ & $0.80 \pm 0.10^{\mathrm{c}}$ & $0.45 \pm 0.10^{\mathrm{b}}$ \\
\hline \multicolumn{5}{|c|}{$\begin{array}{l}\text { Components (g/100 g of dry } \\
\text { product) }\end{array}$} \\
\hline \multicolumn{2}{|c|}{ Dry matter $(\%)$} & $95.66 \pm 0.37^{\mathrm{a}}$ & $95.30 \pm 0.13^{\mathrm{a}}$ & $96.16 \pm 0.64^{\mathrm{a}}$ \\
\hline \multicolumn{2}{|c|}{ Crude protein $(\%)^{\mathrm{N} \times 6.25}$} & $37.30 \pm 1.30^{\mathrm{c}}$ & $35.60 \pm 0.14^{\mathrm{b}}$ & $28.6 \pm 0.15^{\mathrm{a}}$ \\
\hline \multicolumn{2}{|l|}{ Total lipid (\%) } & $36.50 \pm 1.50^{\mathrm{a}}$ & $35.70 \pm 1.20^{\mathrm{a}}$ & $46.40 \pm 0.40^{\mathrm{c}}$ \\
\hline \multicolumn{2}{|l|}{ Ash (\%) } & $3.11 \pm 0.11^{b}$ & $3.70 \pm 0.20^{\mathrm{c}}$ & $2.45 \pm 0.02^{\mathrm{a}}$ \\
\hline
\end{tabular}




\begin{tabular}{|c|c|c|c|}
\hline Carbohydrate (\%) & $23.00 \pm 1.20^{\mathrm{b}}$ & $25.00 \pm 1.02^{\mathrm{c}}$ & $22.40 \pm 1.00^{\mathrm{a}}$ \\
\hline $\begin{array}{l}\text { Energy density (kc } \\
\text { initial product*) }\end{array}$ & $526.5 \pm 5.3^{\mathrm{a}}$ & $499.4 \pm 10.7^{\mathrm{a}}$ & $572.0 \pm 3.7^{b}$ \\
\hline
\end{tabular}

Table 2: Mineral content of indigenous cucurbit seeds (mg/100 $\mathrm{g}$ of initial product).

\begin{tabular}{lccc}
\hline Mineral elements & C. melo & C. mannii & C. lanatus \\
\hline $\mathrm{K}$ & $640.20 \pm 10.00^{\mathrm{b}}$ & $806.10 \pm 21.21^{\mathrm{c}}$ & $500.00 \pm 40.00^{\mathrm{a}}$ \\
$\mathrm{Na}$ & $28.00 \pm 4.11^{\mathrm{b}}$ & $11.00 \pm 2.31^{\mathrm{a}}$ & $43.00 \pm 5.00^{\mathrm{c}}$ \\
$\mathrm{Ca}$ & $1426.00 \pm 50.10^{\mathrm{c}}$ & $102.03 \pm 15.60^{\mathrm{b}}$ & $46.00 \pm 4.00^{\mathrm{a}}$ \\
& $202.00 \pm 15.00^{\mathrm{a}}$ & $366.00 \pm 11.00^{\mathrm{c}}$ & $276.00 \pm 23.00^{\mathrm{b}}$ \\
$\mathrm{Mg}$ & & \\
\hline $\begin{array}{l}\text { Mean } \pm \text { standard deviation of three determinations. In the same row, mean values followed by the same } \\
\text { letter (superscript) are not significantly different }(\mathrm{P}>0.05) .\end{array}$
\end{tabular}

Table 3: Chemical characteristics of cucurbit seed oils.

\begin{tabular}{|c|c|c|c|}
\hline \multirow[t]{2}{*}{ Characteristic } & \multicolumn{3}{|c|}{ Oil types } \\
\hline & C. melo & C. mannii & C. lanatus \\
\hline $\begin{array}{l}\text { Peroxide value } \\
\text { (meq of } \mathrm{O}_{2} / \mathrm{kg} \text { of oil) }\end{array}$ & $2.72 \pm 0.04^{\mathrm{a}}$ & $9.78 \pm 0.10^{\mathrm{c}}$ & $3.35 \pm 0.05^{\mathrm{b}}$ \\
\hline $\begin{array}{l}\text { Iodine value } \\
\text { ( } \mathrm{g} \text { of } \mathrm{I}_{2} / 100 \mathrm{~g} \text { of oil) }\end{array}$ & $115.50 \pm 0.3^{\mathrm{a}}$ & $111.80 \pm 2.00^{\mathrm{a}}$ & $113.00 \pm 3.00^{\mathrm{a}}$ \\
\hline $\begin{array}{l}\text { Acid value } \\
\text { (mg of } \mathrm{NaOH} / \mathrm{g} \text { oil) }\end{array}$ & $2.30 \pm 0.00^{\mathrm{a}}$ & $2.30 \pm 0.02^{\mathrm{a}}$ & $4.30 \pm 0.20^{\mathrm{b}}$ \\
\hline $\begin{array}{l}\text { Free fatty acid } \\
(\% \text { of oleic acid })\end{array}$ & $1.13 \pm 0,00^{\mathrm{a}}$ & $1.13 \pm 0.01^{\mathrm{a}}$ & $2.15 \pm 0.12^{\mathrm{b}}$ \\
\hline Unsaponifiable matter $(\%)$ & $0.53 \pm 0.04^{\mathrm{a}}$ & $0.55 \pm 0.02^{\mathrm{a}}$ & $0.54 \pm 0.10^{\mathrm{a}}$ \\
\hline Colour parameters & & & \\
\hline $\mathrm{L}^{*}$ & $76.12 \pm 0.05^{\mathrm{c}}$ & $67.50 \pm 0.03^{\mathrm{a}}$ & $74.08 \pm 0.01^{\mathrm{b}}$ \\
\hline$a^{*}$ & $-3.55 \pm 0.01^{\mathrm{b}}$ & $-3.70 \pm 0.03^{c}$ & $-2.93 \pm 0.01^{\mathrm{a}}$ \\
\hline$b^{*}$ & $+13.00 \pm 0.02^{\mathrm{b}}$ & $+11.24 \pm 0.01^{\mathrm{a}}$ & $+17.95 \pm 0.02^{\mathrm{c}}$ \\
\hline Chroma & $0.08 \pm 0.01^{\mathrm{a}}$ & $0.09 \pm 0.00^{\mathrm{a}}$ & $0.06 \pm 0.00^{\mathrm{b}}$ \\
\hline
\end{tabular}



Hue angle
$-74.84 \pm 0.15^{\mathrm{b}}$
$-71.78 \pm 0.15^{\mathrm{a}}$
$-80.73 \pm 0.01^{\mathrm{c}}$
Colour
Pale yellow
Green-yellow
Yellow-orange
Bulk density ( $\mathrm{g} / \mathrm{mL})$
$0.95 \pm 0.01^{\mathrm{a}}$
$0.95 \pm 0.01^{\mathrm{a}}$
$0.94 \pm 0.01^{\mathrm{a}}$
Specific gravity
$0.96 \pm 0.02^{\mathrm{a}}$
$0.96 \pm 0.01^{\mathrm{a}}$
$0.95 \pm 0.01^{\mathrm{a}}$

Mean \pm standard deviation of three determinations. In the same row, mean values followed by the same letter (superscript) are not significantly different $(\mathrm{P}>0.05)$.

Table 4: Main fatty acid composition of cucurbit seed oils (\% total fatty acids).

\begin{tabular}{lccc}
\hline Fatty acids & C. melo & C. mannii & C. lanatus \\
\hline $16: 0$ & $10.66 \pm 0.08^{\mathrm{a}}$ & $16.33 \pm 0.29^{\mathrm{a}}$ & $11.87 \pm 0.18^{\mathrm{a}}$ \\
$18: 0$ & $9.02 \pm 0.01^{\mathrm{a}}$ & $13.89 \pm 0.22^{\mathrm{a}}$ & $9.35 \pm 0.16^{\mathrm{a}}$ \\
C18:1n 9 & $9.12 \pm 0.03^{\mathrm{a}}$ & $14.54 \pm 0.13^{\mathrm{a}}$ & $14.43 \pm 0.11^{\mathrm{a}}$ \\
$18: 2 \mathrm{n} 6$ & $70.76 \pm 0.02^{\mathrm{a}}$ & $54.81 \pm 0.13^{\mathrm{a}}$ & $63.94 \pm 0.23^{\mathrm{a}}$ \\
$18: 3 \mathrm{n} 3$ & $0.46 \pm 0.01^{\mathrm{a}}$ & $0.42 \pm 0.02^{\mathrm{a}}$ & $0.43 \pm 0.01^{\mathrm{a}}$ \\
TSFA & $19.68 \pm 0.04^{\mathrm{a}}$ & $30.22 \pm 0.50^{\mathrm{a}}$ & $20.97 \pm 0.24^{\mathrm{a}}$ \\
MUFA & $9.02 \pm 0.01^{\mathrm{a}}$ & $14.54 \pm 0.13^{\mathrm{a}}$ & $14.50 \pm 0.15^{\mathrm{a}}$ \\
PUFA & $71.22 \pm 0.02^{\mathrm{a}}$ & $55.23 \pm 0.14^{\mathrm{a}}$ & $64.54 \pm 0.11^{\mathrm{a}}$ \\
TUFA/TSFA & $4.10 \pm 0.05^{\mathrm{a}}$ & $2.30 \pm 0.02^{\mathrm{a}}$ & $3.81 \pm 0.20^{\mathrm{a}}$ \\
C18:0/C16:0 & $0.85 \pm 0.01^{\mathrm{a}}$ & $0.85 \pm 0.03^{\mathrm{a}}$ & $0.790 .01^{\mathrm{a}}$ \\
\hline
\end{tabular}

Mean \pm standard deviation of three determinations. In the same row, mean values followed by the same letter (superscript) are not significantly different $(\mathrm{P}>0.05)$. MUFA, monounsaturated fatty acids, PUFA, polyunsaturated fatty acids, TUFA, total unsaturated fatty acids, TSFA, total saturated fatty acids.

Table 5: Transition temperatures during melting and cooling processes of cucurbits seed oils.

\begin{tabular}{llcccc}
\hline Curve & \multicolumn{1}{c}{ Sample } & \multicolumn{4}{c}{ Transition temperature $\left({ }^{\circ} \mathbf{C}\right)$} \\
\cline { 3 - 6 } & & $\mathbf{1}$ & $\mathbf{2}$ & $\mathbf{3}$ & $\mathbf{4}$ \\
\hline Melting & C. melo & $-42.3 \pm 0.1^{\mathrm{b}}$ & $-37.3 \pm 0.3^{\mathrm{b}^{\mathrm{*}}}$ & $-11.7 \pm 0.1^{\mathrm{a}}$ & $-4.3 \pm 0.7^{\mathrm{b}}$ \\
& C. mannii & & & & \\
& C. lanatus & $-30.0 \pm 0.0^{\mathrm{a}}$ & $-20.3 \pm 0.8^{\mathrm{c}}$ & $2.5 \pm 0.8^{\mathrm{a}}$ & \\
& & $-36.5 \pm 1.5^{\mathrm{a}}$ & $-18.1 \pm 0.3^{\mathrm{b}}$ & $-8.8 \pm 0.1^{\mathrm{c}}$ & $-1.6 \pm 0.1^{\mathrm{a}}$ \\
\hline Crystallization & C. melo & $-13.0 \pm 0.3^{\mathrm{b}}$ & $-36.5 \pm 0.5^{\mathrm{a}}$ & & \\
& C. mannii & & & & \\
& & $-3.5 \pm 0.1^{\mathrm{a}}$ & $-35.0 \pm 0.2^{\mathrm{a}}$ & & \\
& C. lanatus & $-10.2 \pm 0.2^{\mathrm{c}}$ & $-39.5 \pm 0.5^{\mathrm{b}}$ & &
\end{tabular}

Mean \pm standard deviation of three determinations. In the same row, mean values followed by the same letter (superscript) are not significantly different $(\mathrm{P}>0.05)$. * Exothermic peak. 
Table 6: Comparison of thermal characteristics of cucurbit species seed oils.

\begin{tabular}{llccc}
\hline Curve & \multicolumn{1}{c}{ Sample } & \multicolumn{3}{c}{ Characteristics } \\
\cline { 3 - 5 } & & $\boldsymbol{T}_{\text {on }}\left({ }^{\circ} \boldsymbol{C}\right)$ & $\boldsymbol{T}_{\text {off }}\left({ }^{\circ} \boldsymbol{C}\right)$ & $\boldsymbol{\Delta H}(\boldsymbol{J} / \mathbf{g})$ \\
\hline Melting & C. melo & $-48.7 \pm 1.5$ & $1.4 \pm 0.3$ & $39.0 . \pm 1.1$ \\
& C. mannii & $-39.5 \pm 2.5$ & $13.8 \pm 0.3$ & $47.8 \pm 0.9$ \\
& C. lanatus & $-47.7 \pm 1.2$ & $6.0 \pm 1.7$ & $56.0 \pm 3.0$ \\
\hline Crystallization & C. melo & $-7.2 \pm 0.5$ & $\mathrm{ND}$ & $-24.0 \pm 0.2$ \\
& C. mannii & $1.3 \pm 0.2$ & $\mathrm{ND}$ & $-33.0 \pm 1.0$ \\
& C. lanatus & $-4.4 \pm 0.4$ & $\mathrm{ND}$ & $-25.5 \pm 2.3$ \\
& & &
\end{tabular}

\section{DISCUSSION}

The proximate composition (total crude protein, total crude oil and total carbohydrate) of cucurbit seeds was similar to the composition of cucurbit seeds reported previously (Loukou et al., 2007) and they were higher than amounts reported by others. Nyam et al. (2009) reported that Kalahari melon (C. lanatus) seeds yielded $24.5 \%$ of protein, $30.5 \%$ of oil and $3.3 \%$ of total carbohydrates. De Mello et al. (2000) reported that melon seeds (C. melo hybrid AF-522) from Brazil contained $30.83 \%$ of oil, $14.91 \%$ of proteins and $22.94 \%$ of carbohydrates. Variation in proximate composition of the cucurbit seeds of the same species may be due to the differences in the variety of plant, cultivation climate and the harvesting time of the seeds (Nyam et al., 2009).

The high contents of oil, protein and carbohydrate of cucurbit seeds make them highly energetic. The high percentage of oil makes these seeds suitable for oil industry application.

The levels of these minerals of cucurbit seeds were higher than values found by Besbes et al. (2004) for two varieties of date seeds (Potassium: 229-293 mg/100 g; magnesium: $51.7-58.4 \mathrm{mg} / 100 \mathrm{~g}$; sodium: 10.25 and $10.40 \mathrm{mg} / 100 \mathrm{~g}$, calcium: 28.9 and $38.8 \mathrm{mg} / 100 \mathrm{~g}$ ). The mineral contents of cucurbit seeds were also much higher than those found by Onyeike and Ancheru (2002) for groundnut and palm kernel. Data showed that cucurbit seeds were an important source of many mineral elements.

The peroxide value and the free fatty acids were among the important characteristics to determine the present condition and quality of oil sample. The high value of peroxide value of $C$. mannii oil shows that it is more unstable than the two other cucurbit seed oils. These values are lower than values for groundnut oil (20.0 meq $\mathrm{O}_{2} / \mathrm{kg}$ of oil) reported by Onyeike and Ancheru (2002) and for Astorcarpus heterphyllus seed oil (15.0 meq $/ \mathrm{kg}$ of oil) reported by Ajayi (2008). Tan et al. (2002) reported the peroxide values of some edible oils: canola oil (6.68 meq $\mathrm{O}_{2} / \mathrm{kg}$ of oil), olive 
oil (8.50 meq $\mathrm{O}_{2} / \mathrm{kg}$ of oil), refined-bleacheddeodorized palm plein $\left(0.82 \mathrm{meq} \mathrm{O}_{2} / \mathrm{kg}\right.$ of oil $)$ and sunflower oil ( $9.10 \mathrm{meq} \mathrm{O}_{2} / \mathrm{kg}$ of oil). Oil whose peroxide value was lower than $10 \mathrm{meq}$ $\mathrm{O}_{2} / \mathrm{kg}$ of oil, was recommended for edible vegetable oils by Codex Alimentarius Commission (1982). According to Ojeh (1981), oils with high peroxide values are unstable and easily become rancid (having a disagreeable odour). The peroxide value of cucurbit seed oils studied in the present work suggests that they can be stored for long period without deterioration. The iodine value indicated the degree of unsaturation of seed oil. Iodine values of cucurbit seeds investigated here, were higher than iodine value of groundnut seed oil, 11.2 and palm kernel oil, 33.3 found by Onyeike and Ancheru (2002). They were comparable to the values found by Badifou (1991a) for $C$. mannii (110.9), for L. sicceraria var. 1 (115) and for L. sicceraria var. 2 (122.9). The higher iodine values for the species in this study were due to their high content in total unsaturated fatty acids mainly linoleic acid.

The total acidity of these oils varied from 2.30 to 4.30 (Table 3), showing that these oils could be considered as edible oils and could have long shelf life. The free fatty acid values of oils investigated were comparable of the value of sesame oil $(2.37 \%)$ reported by Tan et al. (2002). According to Dosunmu and Ochu (1995), the Chryosophyllum albidum seed oil with free fatty acid reached to $1.81 \%$ and the Cola rostata seed oil with $5.0 \%$ supported the point of view that these oils are edible.

The lightness $\left(\mathrm{L}^{*}\right)$ of $C$. melo and $C$. lanatus seed oils showed that they contained more yellow pigments and C. mannii seed oil contained more chlorophyll pigments. The fatty acid composition patterns of investigated cucurbit seed oils are characteristic of most species of cucurbits published by other authors (Badifou, 1991a; De Mello et al., 2001). Linoleic acid is one of the most important polyunsaturated fatty acids (n-6) in human food because of its positive health benefit and also its essential fatty acid for human (Omode et al., 1995; Pastor-Cavada et al., 2009). In this study, the total polyunsaturated fatty acids of $C$. melo is higher than total polyunsaturated fatty acids $(51.79 \%)$ of $C$. melo oil reported by De Mello et al. (2001).

On the nutritional aspect, consumption of foods rich in saturated fatty acids from $\mathrm{C} 12$ to $\mathrm{C} 16$ was positively associated with lowdensity lipoprotein and cardiovascular disorders, whereas C18:0 was considered neutral in this respect (Schaefer, 1997). According to Emken (1994), C18:0 was less hypercholesterolemic than C16:0. The amount of unsaturated n- 6 was very high in the three oils, therefore the TUFA/TSFA ratio ranged from 2.30 to $4.10 \%$ of investigated oils was higher than the ratio recommended by FAO report (1994) which was between $0.84 \%$ and $1.16 \%$.

The DSC melting and cooling curves of the three cucurbits seed oils were characterized by the presence of multiple endothermic and exothermic peaks. According to Tan and Che Man (2002), It was due to a variety of reasons in which two major causes predominate: the first was the unique features in the triacylglycerol (TAG) distribution and the other was the melting-recrystallization of the original TAG crystallites and their subsequent melting known as the polymorphism phenomenon. As the oil samples are heated, some of the less thermally-stable polymorphs melt; the remaining TAG rearrange and recrystallize into more stable polymorphs that melt at higher temperatures. On the other hand, when a partial melting of a polymorph, accompanied by conversion or transition to a higher polymorph takes place, both endothermic peak and endothermic changes are represented in a single endothermic peak. That can explain the phenomenon that 
occurred with the $C$. melo seed oil heating curve which exhibited exothermic peak at $-37.3{ }^{\circ} \mathrm{C}$ before melting phenomenon during heating process.

The low melting temperatures, (from $-43.0{ }^{\circ} \mathrm{C}$ to $-30{ }^{\circ} \mathrm{C}$ ) might be attributed to highly unsaturated TAG rich in linolenic and linoleic acids. The transition temperatures (from -20.0 to -8.8) might be attributed to the unsaturated TAG rich in linoleic acids and the high melting temperatures for TAG rich in saturated fatty acids. Generally, the oil samples with high content of unsaturated fatty acid showed DSC melting and crystallization profiles at lower temperature regions (onset and offset temperatures) and required less energy during the melting process compared to the oil samples with high content of saturated fatty acids. Enthalpy of oil explains whether oil changes from one physical state to another by absorbing (endothermic) or releasing (exothermic) heat (Zhao and Yalkowsky, 1999). The data obtained are useful to control fractionation of oil during industrial production.

\section{Conclusion}

In general, the three species of cucurbit seeds investigated in this study are good sources of nutrients: proteins, oils, carbohydrates and mineral elements. The knowledge of the characteristics of their oils seems interesting for industrial and nutritional application, for example in feeding supplementation. The high linoleic content of these seed oils makes them nutritionally valuable. The $C$. melo seed oil contains the highest amount of unsaturated fatty acid and the $C$. mannii seed oil contains the highest amount of saturated fatty acids. C. melo seed oil exhibited a lowest melting point compared to $C$. lanatus and $C$. mannii seed oils. These thermal properties could be used in the industrial fractionation. Due to their similarity to the common used edible oils, this study suggests that the cucurbit seed oils may be used as edible oils.

\section{ACKNOWLEDGEMENTS}

We would like to thank Agence Universitaire de la Francophonie (AUF) for their financial support for this project. We are also grateful to the Laboratory of Engineering and Biomolecule of Institut National Polytechnique de Lorraine (France) where we carried out this study.

\section{REFERENCES}

Ackman RG. 1998. Remarks of on official methods employing boron trifluoride in preparation of methyl ester of fatty acids of fish oils. Journal of the American Oil Chemists' Society, 75: 541-545.

Ajayi IA. 2008. Comparative study of the chemical composition and mineral element content of Artocarpus heterophyllus and Treculia africana seeds and seed oils. Bioresource Technology, 99: 5125-5129.

AOAC (Association. of Official of Analytical Chemists). 1997. Official Methods of Analysis (15th edn). AOAC: Washington, D.C.

AOCS (American Oil Chemists' Society). 1997. Official Methods of Analysis 965.33. Peroxide Value of Oils and Fat. American Oil Chemists' Society.

Atwater WO, Benedict FG. 1902. Experiments on the metabolism of matter and energy in human body, 1898-1900, United States. Office of experiment stations. Bulletin $\mathrm{N}^{\circ}$ 109. Government Printing Office, Washington, D.C.

Badifu GIO. 1991a. Chemical and physical analyses of oil from four species of cucurbitaceae. Journal of the American Oil Chemists' Society, 68(6): 428-431.

Badifu GIO. 1991b. Unsaponifiable matter in oils from some species of cucurbitaceae. Journal of Food Composition and Analysis, 4: 360-365.

Badifu GIO. 2001. Effect of processing on 
proximate composition, antinutritional and toxic contents of kernels from cucurbitaceae species grown in Nigeria. Journal of Food Composition and Analysis, 14: 153-161.

Besbes S, Blecker C, Deroanne C, Drira NE, Attia H. 2004. Dates seeds: chemical composition and characteristic profiles of the lipid fraction. Food Chemistry, 84: 577-584.

Codex Alimentarius Commission. 1982. Recommended Internal Standards Edible Fats and Oil (1st edn, Vol. IX). FAO/WHO: Rome, Italy.

De Mello MLS, Narain N, Bora PS. 2000. Characterization of some nutritional constituents of melon (Cucumis melo hybrid AF-522) seeds. Food Chemistry, 68: 411-414.

De Mello MLS, Bora PS, Narain N. 2001. Fatty and amino acids composition of melon (Cucumis melo Var. saccharinus) seeds. Journal of Food Composition and Analysis, 14: 69-74.

Dosunmu MI, Ochu C. 1995. Physicochemical properties and fatty acid composition of lipids extracted from Nigeria fruit and seeds. Global Journal of Pure Applied Science, 1(1/2): 45-50.

Emken EA. 1994. Metabolism of dietary stearic acid relative to other fatty acids in human subjects. American Journal of Clinical and Nutrition, 60: S1023S1028.

FAO/WHO. 1994. Fats and oils in human nutrition. Report of the joint expert consultation. FAO Food and Nutrition Paper $N^{\circ} 57$.

Folch J, Lees M, Stanley GHS. 1957. A simple method for the isolation and purification of total lipids from animal sources. Journal of Biology and Chemistry, 226: 497-509.

Idouraine A., Kohlhepp EA, Webber CW. 1995. Nutrient constituents from eight lines of naked seed squash. Journal of the Agricultural and Food Chemistry, 44: 721-724.

Loukou AL, Gnakri D, Djè Y, Kippré AV, Malice M, Baudoin JP, Zoro Bi IA. 2007. Macronutrient composition of three cucurbit species cultivated for seed consumption in Côte d'Ivoire. African Journal of Biotechnology, 6(5): 529-533.

Norme Européenne. 1999. Corps gras d'origines animale et végétale Détermination de l'indice d'acide et de l'acidité. Norme Française NF EN ISO 660, $T$ 60-204.

Norme Européenne. 1999. Corps gras d'origines animale et végétale - Dosage de l'indice d'iode. Norme Française NF EN ISO 3961, T 60-203.

Norme Internationale. 2000. Animal and vegetable fats and oils - Determination of unsaponifiable matter - Method using hexane extraction. ISO 18609.

Nyam KL, Tan CP, Lai OM, Long K, Che Man YB. 2009. Physicochemical properties and bioactive compounds of selected seed oils. LWT-Food Science and Technology: doi:10.1016/j.lwt. 2009.03.006.

Ojeh O. 1981. Effects of refining on the physical and chemical properties of cashew kernel oil. Journal of Fats and Oil Technology, 1b: 513-517.

Omode AA, Fatoki OS, Olaogune KA. 1995. Physicochemical properties of some under- exploited and non conventional oil seeds. Journal of Agricultural Food Chemistry, 43: 2850-2853.

Onyeike EN, Ancheru GN. 2002. Chemical composition of selected seed Nigerian oilseeds and physicochemical properties of the oil extracts. Food Chemistry, 77: 431-437.

Pastor-Cavada E, Juan R, Pastor JE, Alaiz M, Vioque J. 2009. Chemical composition and nutritional characteristics of the seed oil of wild Lathyrus, Lens and Pisum species from southern spain. Journal of 
the American Oil of Chemists' Society: doi: 10.1007/s11746-009-1352-0.

Rashwan, MRA, El-Syiad SI, Seleim MA. 1993. Protein solubility, mineral content, amino acid composition and electrophoretic patern of gourd seeds. Acta Aliment, 22(1): 15-24.

Samant SK, Rege DV. 1989. Carbohydrate composition of some cucurbit seeds. Journal of Food Composition and Analysis, 2: 149-156.

Schaefer EJ. 1997. Effect of dietary fatty acids on lipoprotein and cardiovascular disease risk: Summary. American Journal of Clinical and Nutrition, 65: S1655S1656.

Tan CP, Che Man YB. 2002. Differential scanning calorimetric analysis of palm oil, palm oil based products and coconut oil: effects of scanning rate variation. Food Chemistry, 76: 89-102.

Tan CP, Che Man YB, Selamat J, Yusoff MSA. 2002. Comparative studies of stability of edible oils by differential scanning calorimetric and oxidative stability index methods. Food Chemistry, 76: 385-389.

Toetia MS, Ramakrishna P. 1984. Chemistry and technology of melon seeds. Journal of Food Science and Technology, 21: 332-337.

Zhao L, Yalkowsky SH. 1999. A combined group contribution and molecular geometry approach for predicting melting points of aliphatic compounds. Industrial and Engineering Chemistry Research, 38: 3581-3584.

Zoro Bi I, Koffi KK, Djè Y, Malice M, Badoin JP. 2006. Indigenous cucurbits of Côte d'Ivoire: a review of their genetic resources. Science \& Nature, 3(1): 1-9. 